\title{
A Chemostat Study of the Effect of Fixed Nitrogen Sources on Nitrogen Fixation, Membranes and Free Amino Acids in Azotobacter chroococcum
}

\author{
By J. W. DROZD, R. S. TUBB AND J. R. POSTGATE \\ A.R.C. Unit of Nitrogen Fixation, University of Sussex, \\ Brighton, BN I $9 Q J$, Sussex
}

(Received 15 May I972)

\begin{abstract}
SUMMARY
Increasing concentrations of ammonium ions in the medium of nitrogen-fixing, sulphate-limited continuous cultures of Azotobacter chroococcum caused a proportionate repression of nitrogenase activity; free $\mathrm{NH}_{4}{ }^{+}$could be detected in the extracellular culture fluid only when nitrogenase activity was wholly repressed. The $\mathrm{NH}_{4}{ }^{+}$concentrations giving $50 \%$ or $100 \%$ repression were proportional to the population density. Nitrate ions repressed with similar stoichiometry; glutamate, glutamine and aspartate did not repress and were not metabolized; repressed and derepressed populations contained equal amounts and proportions of glutamateforming enzymes. Repressed populations lacked both enzymatic components of nitrogenase. The intracellular free amino acid pools were typical of Gram-negative bacteria; an increase in the degree of repression was associated with an increase in the pool levels of ammonia, aspartate and glutamate. Nitrogen-fixing populations possessed a convoluted intracytoplasmic membrane system which was absent from ammonia-assimilating organisms, but the phospholipid contents of the two types of population were similar. All members of a half-repressed population possessed these membranes, but to a lesser extent that fully derepressed populations.

When $\mathrm{N}_{2}$-fixing chemostat populations were abruptly exposed to repressive concentrations of ammonium succinate, repression occurred exponentially and nitrogenase activity disappeared from the culture faster than wash-out of stable enzyme. Repression was not alleviated by exogenous cyclic AMP. Derepression was complete, according to the acetylene test, within half a doubling time of disappearance of free ammonium ions from the culture.
\end{abstract}

\section{INTRODUCTION}

The fact that sources of fixed nitrogen, such as ammonia, nitrate or urea, repress synthesis of nitrogenase by nitrogen-fixing bacteria has been known for many years (see Wilson, 1958). Klebsiella pneumoniae (Goerz \& Pengra, 196r ; Yoch \& Pengra, I966; Mahl \& Wilson, I967) showed a diauxic growth pattern on transfer from ammonia-assimilating to nitrogen-fixing conditions and a decreased lag in nitrogenase synthesis when amino acids were supplied; there was evidence that ammonia exerted its effect on synthesis rather than on activity of the enzyme. Parejko \& Wilson (1970) showed that K. pneumoniae synthesized nitrogenase in vacuo, thus providing strong circumstantial (but not conclusive) evidence that nitrogenase synthesis was a derepression and not an induction phenomenon, a conclusion also indicated by chemostat studies in which ammonia-limited populations of Clostridium pasteurianum 
(Daesch \& Mortenson, 1968) and Azotobacter chroococcum (Dalton \& Postgate, I969b) synthesized nitrogenase under helium or argon. Nitrogenase synthesis under an inert gas has also been shown with Rhodospirillum rubrum (Munson \& Burris, 1969) and the bluegreen algae Anabena cylindrica (Smith \& Evans, I970; Neilson, Rippka \& Kunisawa, I97I) and Anabena flos-aquae (Bone, 1971).

Strandberg \& Wilson (1968) observed diauxic growth on derepression in Azotobacter vinelandii; nitrogenase activity appeared about $45 \mathrm{~min}$ after exhaustion of ammonia. Sorger (I968) claimed that 2-methylalanine or methylamine acted as co-repressors in this species but St John \& Brill (I972) showed that this was a growth inhibition effect specific to glucose media. Shah, Davis \& Brill (I972) studied repression and derepression of nitrogenase in $A$. vinelandii and showed that both components of the enzyme were repressed co-ordinately; electron-paramagnetic-resonance signals attributable to the iron-molybdenum protein appeared or disappeared according to the state of repression (Davis, Shah, Brill \& OrmeJohnson, I972). Hardy, Holsten, Jackson \& Burns ( I968) mentioned that, besides repressing synthesis, ammonium ions had an immediate inhibitory effect on nitrogenase activity in whole organisms which did not occur with extracts. Oppenheim \& Marcus (I970 a) reported that the elaborate cytoplasmic membrane network of $A$. vinelandii (Pangborn, Marr \& Robrish, I962) was absent from presumptive repressed populations: those grown with nitrate or ammonia.

Chemostat culture has certain advantages for studying control of nitrogenase syntheses: nutritional status, which can lead to considerable differences in relevant assimilating enzymes, can be controlled; so can growth rate, and this is important since $\mu_{\max }$ is usually different as between ammonia-assimilating and nitrogen-fixing cultures of the same bacteria. Steady states may be obtained with partially repressed populations and population density may be controlled independently. We report here a study, making use of this technique, of the regulation of nitrogenase activity in Azotobacter chroococcum.

\section{METHODS}

Organism and culture. Azotobacter chroococcum (NCIB 8003) was grown in continuous culture (Baker, I968) at $30 \pm 0.5{ }^{\circ} \mathrm{C}$ and $\mathrm{pH} 6.8$ to 7.2 as described by Drozd \& Postgate (1970); automatic $\mathrm{pH}$ control was used with cultures assimilating $\mathrm{NH}_{4} \mathrm{Cl}$; oxygen tension was monitored with a Clark type oxygen electrode.

A medium allowing growth limitation in the nitrogen-assimilating pathway was inappropriate for the present study. Carbon and phosphate limitation would involve complication due to hypersensitivity of the population to oxygen inhibition (Dalton \& Postgate, I $969 a$ ) so sulphate limitation was chosen for chemostat culture because such populations were not hypersensitive. The mannitol medium of Drozd \& Postgate (1970) was prepared but without sulphate and all trace elements as their chlorides; $\mathrm{Na}_{2} \mathrm{SO}_{4}$ was then added to $0.05 \mathrm{~mm}$. Media with sucrose as carbon source or with different sulphate concentrations were used occasionally where mentioned. $\mathrm{KNO}_{3}, \mathrm{NH}_{4} \mathrm{Cl}$ or diammonium succinate solutions were sterilized independently and added aseptically. Automatic $\mathrm{pH}$ control was not necessary when ammonium succinate was used in place of $\mathrm{NH}_{4} \mathrm{Cl}$. The atmosphere was either air or mixtures of $\mathrm{N}_{2}+\mathrm{O}_{2}$ from cylinders, flowing at about $200 \mathrm{ml} / \mathrm{min}$. The oxygen content of the atmosphere, which ranged from 0.1 to 0.3 atm according to the population density, was adjusted to avoid both oxygen limitation and oxygen toxicity by sustaining 5 to I $5 \mu \mathrm{M}$ dissolved $\mathrm{O}_{2}$. The criteria of nutrient limitation were those of Hill, Drozd \& Postgate (1972). 
Acetylene reduction was measured in culture samples and bacterial extracts as described by Drozd \& Postgate (1970). Measurements were made at five different $\mathrm{pO}_{2}$ values to obtain the maximum rate of acetylene reduction for each sample. No additional sulphate was needed with samples from the sulphate-limited chemostat cultures provided the assay was completed in I h.

Bacterial extracts. Sonic disruption was used as described by Drozd \& Postgate (1970). Osmotic lysis was based on the procedure of Oppenheim \& Marcus (1970): the centrifuged culture sample was resuspended in 3 to $4 \mathrm{ml} 4 \mathrm{M}$-glycerol which had been sparged with $\mathrm{N}_{2}$. After $\mathrm{I} \mathrm{h}$ at room temperature (I 8 to $20^{\circ} \mathrm{C}$ ) the suspension was centrifuged at I $2000 \mathrm{~g}$ (Io $\mathrm{min}, 5^{\circ} \mathrm{C}$ ) and the supernatant liquid discarded. The pellet was 'loosened ' under a stream of $\mathrm{N}_{2}$ on a mechanical agitator and sonicated with 4 to $8 \mathrm{ml}$ of $\mathrm{N}_{2}$-sparged $0.025 \mathrm{M}$-tris- $\mathrm{HCl}$ buffer ( $\mathrm{pH} 7 \cdot 4$ ), sometimes containing $0.09 \mathrm{M}-\mathrm{MgCl}_{2}+0.2 \mathrm{mg}$ dithiothreitol $/ \mathrm{ml}$, with a small crystal of DNase to prevent the extract becoming viscous. Sedimentation at $38000 \mathrm{~g}$ for 20 min gave a nitrogenase-containing supernatant fluid and a membranous pellet.

Chromatography. Anaerobic column chromatography of the extracts at $5{ }^{\circ} \mathrm{C}$ on DEAEcellulose 32 was based on the method of Kelly, Klucas \& Burris (1967). Elution was with $0.15 \mathrm{M}-\mathrm{NaCl}, 0.26 \mathrm{M}-\mathrm{NaCl}$ and $0.09 \mathrm{M}-\mathrm{MgCl}_{2}$ respectively, all in $0.025 \mathrm{M}$-tris- $\mathrm{HCl}$ buffer $(\mathrm{pH} 7 \cdot 4)$.

Electron microscopy. Membrane preparations were fixed by the method of Kellenberger, Ryter \& Sechaud ( 1958 ) with $\mathrm{I}_{\%} \mathrm{OsO}_{4}$ in veronal acetate buffer $(\mathrm{pH} 6 \cdot 0)$. Fixed preparations were dehydrated in a graded series of mixtures of ethanol and water with a final wash in acetone, and then embedded in Epon $8 \mathrm{I} 2$ by the method of Luft (I96I). The blocks were cured for $48 \mathrm{~h}$ at $60{ }^{\circ} \mathrm{C}$ and then thin sections were cut with glass knives using a LKB Ultrotome ultramicrotome and were mounted on copper grids. Sections were stained with saturated uranyl acetate in $50 \%$ ethanol for 15 to $30 \mathrm{~min}$ and then soaked in lead citrate (Reynolds, I963). Samples were examined in a A.E.I. 6B electron microscope operating at $60 \mathrm{kV}$.

Lipid phosphorus analyses were based on the method of Lascelles \& Szilagyi (I965). Trichloracetic acid was added to culture samples containing 5 to $20 \mathrm{mg}$ protein until its concentration reached $5 \%$. After centrifugation, the pellet was resuspended in $10 \mathrm{ml} 5 \%$ trichloroacetic acid and recentrifuged. The supernatant was completely removed and the pellet homogenized in $5 \mathrm{ml}$ of chloroform + methanol $(2: \mathrm{I}, \mathrm{v} / \mathrm{v})$. After centrifuging the supernatant was collected and the pellet re-extracted with a further $5 \mathrm{ml}$ of extraction mixture. The combined supernatants were made up to 10 to $15 \mathrm{ml}$ and extracted with aqueous calcium chloride (Folch, Lees \& Sloane-Stanley, 1957) to remove non-lipid material. Total phosphorus was determined in 0.5 to $\mathrm{I} \cdot 0 \mathrm{ml}$ samples of the lipid extract by the method of Bartlett (1959). In one experiment mentioned in the text, total extractable lipid and phospholipid were determined for us.

Amino acid pools. A volume of culture containing approximately $30 \mathrm{mg}$ equivalent dry $\mathrm{wt}$ organisms was centrifuged at $3000 \mathrm{~g}$ for $3 \mathrm{~min}$. The pellet was resuspended in $5 \mathrm{ml}$ of water and the tube capped and placed in boiling water for $5 \mathrm{~min}$. Further centrifugation at $3000 \mathrm{~g}$ for $3 \mathrm{~min}$ gave a clear supernatant, samples of which were applied to the column of a Locarte amino acid analyser previously calibrated with a standard solution of mixed amino acids. For estimating $\mathrm{NH}_{3}$, a small correction was made for $\mathrm{NH}_{3}$ in the buffers; the interstitial and cell-bound water was taken to be four times the dry wt (Roberts et al. 1955).

Analyses and assays. Ammonia was estimated with Nessler's reagent. Respiratory activity was measured directly on culture samples in Warburg manometers (Drozd \& Postgate, I970); protein was estimated as described by those authors, culture samples and membrane 
preparations being first digested with $\mathrm{N}-\mathrm{NaOH}$ for $5 \mathrm{~min}$ in boiling water. Nitrite was assayed with $\alpha$-naphthylamine and nitrate with I,2,4-phenoldisulphonic acid (Boltz, 1958).

Glutamate dehydrogenase (GDH) and GOGAT [glutamine(amide)-2-oxoglutarate aminotransferase oxido-reductase; glutamate synthetase] (NADP) were assayed as described by Meers, Tempest \& Brown (1970).

\section{RESULTS}

Sulphate-limited culture of Azotobacter chroococcum. Chemostat cultures grown without ammonium salt and with $2 \cdot 35 \mathrm{~mm}-\mathrm{NH}_{4} \mathrm{Cl}$ (sufficient to repress nitrogenase synthesis completely - see below) showed little dependence of biomass on dilution rate above $D=0 \cdot \mathrm{I} \mathrm{h}^{-1}$ but a marked increase in biomass at lower growth rates; at such growth rates most organisms contained large, refractile granules, probably poly- $\beta$-hydroxybutyrate. The critical wash-out point occurred at a faster dilution rate $\left(0.45 \mathrm{~h}^{-1}\right)$ when ammonia was being assimilated than when nitrogen was being fixed $\left(0.33 \mathrm{~h}^{-1}\right)$. Curves illustrating these features, with cultures grown at $p \mathrm{O}_{2}=0.3 \mathrm{~atm}$ and $0.025 \mathrm{mM}-\mathrm{Na}_{2} \mathrm{SO}_{4}$, were given by Hill et al. (I972). The yield coefficients at $D=0.2 \mathrm{~h}^{-1}$ for such populations were $200 \mathrm{mg}$ dry wt/g-ion $\mathrm{SO}_{4}{ }^{2-}$ when fixing $\mathrm{N}_{2}, 242$ with $\mathrm{NH}_{3}$. The difference may partly reflect the known high sulphur content of nitrogenase, which was absent from the population grown with $\mathrm{NH}_{3}$ (below); the yields were in the range (200 to 240 ) recorded for Klebsiella aerogenes (syn. Aerobacter aerogenes) in sulphate-limited chemostat cultures (Postgate \& Hunter, 1962).

Membrane and phospholipid content of Azotobacter chroococcum. An internal membrane network specific to nitrogen-fixing $A$. chroococcum analogous to that in $A$. vinelandii, was reported by Hill et al. (1972). The network was not satisfactorily visible in thin sections of whole organisms because other structures interfered, but it was clear in osmotically lysed preparations. Hill et al. (1972) published electron micrographs, which will not be repeated here, and reported that nitrogen-fixing organisms contained some $70 \%$ more phospholipid than ammonia-repressed populations. We have not been able to confirm this report. In one of several further experiments, the phospholipid contents of sextuplicate samples of populations grown at $D=0.25 \mathrm{~h}^{-1}, p \mathrm{O}_{2}=0.2 \mathrm{~atm}$ and $\mathrm{Na}_{2} \mathrm{SO}_{4}=0.05 \mathrm{mM}$ was $92(s=5.5)$ nmol phospholipid $\mathrm{P} / \mathrm{mg}$ bacterial protein when fully derepressed and $94(s=8 \cdot 0)$ when growing with a fully repressive concentration $\left(6 \cdot 4 \mathrm{mM}^{-\mathrm{NH}_{4}}{ }^{+}\right)$of ammonium succinate. However, values ranging from 74 to over 200 have been obtained in our hands and the reasons for this variability, which may well be an analytical artifact, still elude us. Samples of such cultures were kindly analysed by Dr D. Ellwood of the Microbiological Research Establishment, Porton, Wiltshire, who confirmed that the phospholipid contents of wholly repressed and derepressed populations were similar. He also reported that the amounts of total extractable lipids were similar to within $3 \%$.

Steady states with partially repressed populations. Preliminary experiments showed that $0.1 \%$ (I $8.7 \mathrm{mM}) \mathrm{NH}_{4} \mathrm{Cl}$ added to the sulphate-limited medium completely repressed nitrogenase synthesis according to the acetylene test. Graded concentrations of $\mathrm{NH}_{4} \mathrm{Cl}$ were added to a culture limited with $\mathrm{Na}_{2} \mathrm{SO}_{4}$ and steady states in which nitrogenase was partially repressed according to the acetylene test were obtained. Data were collected from such populations only after at least four doublings in the steady state. The optimal $p \mathrm{O}_{2}$ for acetylene reduction was determined for each steady state because this shifted to lower $p \mathrm{O}_{2}$ values as the steady-state nitrogenase content declined. Automatic $\mathrm{pH}$ control corrected for increased acidity in the environment as the shift to ammonia utilization proceeded. Fig. I records a more detailed series of experiments following those provisionally reported by Hill et al. (1972); it shows (i) that free $\mathrm{NH}_{3}$ only became detectable in the medium when 


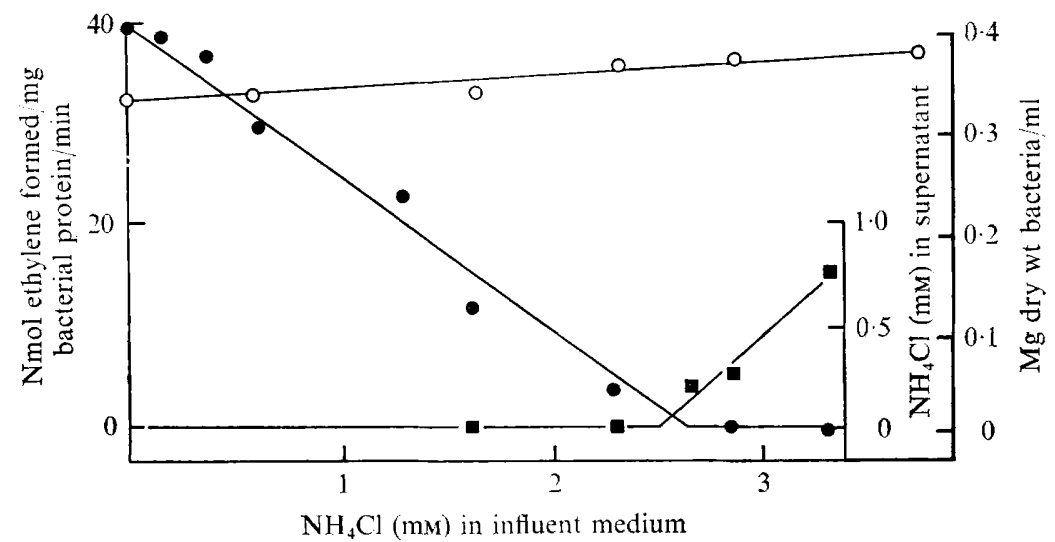

Fig. I. Effect of increasing concentrations of $\mathrm{NH}_{4} \mathrm{Cl}$ in the medium inflow of a $\mathrm{SO}_{4}^{2-}$-limited chemostat culture growing in $\mathrm{N}_{2}+0.3 \mathrm{~atm} \mathrm{O}_{2}\left(50 \mathrm{~mm}-\mathrm{Na}_{2} \mathrm{SO}_{4}, D=0.2 \mathrm{~h}^{-1}\right)$ of Azotobacter chroococcum on the steady-state parameters. $O$, Bacterial concentration; $\boldsymbol{\theta}$, nitrogenase activity of the culture; $\mathbf{m}$, concentration of $\mathrm{NH}_{4} \mathrm{Cl}$ in the culture supernatant.

Table I. Minimum repressive concentration of $\mathrm{NH}_{4} \mathrm{Cl}$ for sulphate-limited chemostat cultures of Azotobacter chroococcum

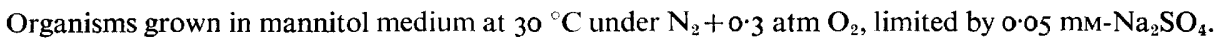

\begin{tabular}{|c|}
\hline $\begin{array}{l}\text { Dilution } \\
\text { rate } \\
\left({ }^{-1}\right)\end{array}$ \\
\hline 0.09 \\
\hline 0.20 \\
\hline 0.29 \\
\hline
\end{tabular}

$\mathrm{NH}_{4} \mathrm{Cl}(\mathrm{mm})$ required
for suppression of
nitrogenase activity

3.05
$2 \cdot 67$

$2 \cdot 48$

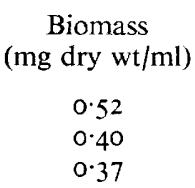

nitrogenase synthesis was wholly repressed; (ii) that, contrary to our earlier impression, biomass did increase measurably over the transition from nitrogen fixation to ammonia assimilation, but that the increase was very slight and entirely consistent with the increased yield of ammonia-assimilating organisms mentioned earlier.

Electron microscopy of thin sections of osmotically lysed bacteria from a half-repressed population showed that all had a moderate amount of internal membrane structure. Hence the population was uniformly half repressed, not a mixture of fully repressed and fully derepressed organisms.

Effect of dilution rate. Minimum concentrations of $\mathrm{NH}_{4} \mathrm{Cl}$ required for complete repression of nitrogenase at various dilution rates are given in Table I. Biomass increased about $40 \%$ while the minimum repressive ammonia concentrations increased by about $20 \%$ with decreasing growth rate over the range tested; the latter increase was paralleled by the $\mathrm{N}$ content of the culture.

Effect of population density. Preliminary experiments suggesting that the concentrations of ammonia required to repress fully or to half-repress nitrogenase activity depended on population density were mentioned by Hill et al. (1972). Chemostats were set up at a fixed dilution rate with different sulphate concentrations so as to obtain different population densities; the $p \mathrm{O}_{2}$ of the atmosphere was adjusted to avoid oxygen inhibition at low sulphate concentration (a $\mathrm{OO}_{2}$ of $\mathrm{O}^{\mathrm{I}} \mathrm{I}$ atm was used at the lowest population densities). Fig. 2 shows that the concentration of $\mathrm{NH}_{4} \mathrm{Cl}$ required to half-repress populations and the minimum concentration needed to repress fully were proportional to population density. 


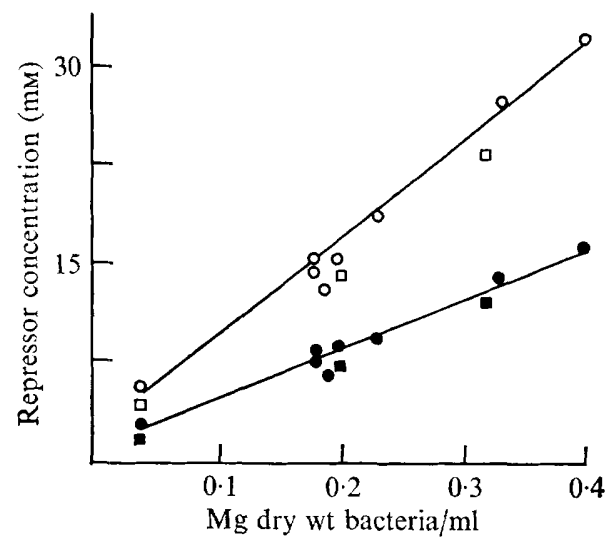

Fig. 2. The effect of the bacterial population density (controlled by the concentration of $\mathrm{Na}_{2} \mathrm{SO}_{4}$ in the inflowing medium) in $\mathrm{SO}_{4}{ }^{2-}$-limited chemostat culture, $D=0.2 \mathrm{~h}^{-1}$, of Azotobacter chroococcum on the concentration of repressor required to $100 \%$ repress (open symbols) or $50 \%$ repress (closed symbols) the nitrogenase activity of the culture. $\bigcirc, \bullet, \mathrm{NH}_{4} \mathrm{Cl} ; \square, \mathbf{\square}, \mathrm{KNO}_{3}$.

Table 2. Influence of the degree of repression of nitrogenase synthesis by $\mathrm{KNO}_{3}$ or $\mathrm{NH}_{4} \mathrm{Cl}$ on the free ammonia and amino acid pool contents of chemostat cultures, $D=0.2 h^{-1}$, of Azotobacter chroococcum limited by $0.05 \mathrm{~mm}-\mathrm{Na}_{2} \mathrm{SO}_{4}$ under $\mathrm{N}_{2}+0.3 \mathrm{~atm} \mathrm{O}_{2}$

For details see Methods. Concentrations (mM) of amino acids in extracts assessed as peak areas of traces from the automatic amino acid analyser. Water content assumed to be four times the bacterial dry weight. Iso-leucine, leucine, methionine, proline, phenylalanine and tyrosine were not detected (less than 0. I I mM).

\begin{tabular}{|c|c|c|c|c|c|}
\hline & \multicolumn{5}{|c|}{ Repressor } \\
\hline & None & & & & \\
\hline \multirow{2}{*}{$\begin{array}{l}\text { Pool } \\
\text { material }\end{array}$} & \multicolumn{5}{|c|}{ Degree of repression } \\
\hline & 0 & $50 \%$ & $100 \%$ & $50 \%$ & $100 \%$ \\
\hline $\mathrm{NH}_{3}$ & $2 \cdot 0$ & $3 \cdot 6$ & $5 \cdot 0$ & $3 \cdot 8$ & $5 \cdot 7$ \\
\hline Glutamate & $x \cdot 2$ & $3 \cdot 6$ & $4 \cdot 6$ & $3 \cdot 9$ & $7 \cdot 3$ \\
\hline Aspartate & $0 \cdot 23$ & 0.48 & $\mathrm{I} \cdot 0$ & $\mathrm{I} \cdot \mathbf{2}$ & $3 \cdot 2$ \\
\hline Alanine & 0.84 & $0.8 \mathrm{I}$ & 0.54 & 0.60 & $I \cdot 0$ \\
\hline Arginine & 0.21 & 0.22 & O.II & 0.18 & 0.22 \\
\hline Glycine & 0.21 & 0.27 & $0 \cdot 16$ & 0.38 & 0.38 \\
\hline Histidine & 0.49 & 0.52 & 0.36 & $0 \cdot 80$ & $\mathrm{I} \cdot 4$ \\
\hline Lysine & 0.28 & 0.23 & 0.18 & 0.30 & 0.50 \\
\hline Serine & 0.21 & 0.35 & 0.60 & 0.38 & 0.80 \\
\hline Threonine & - & - & 0.22 & - & $I \cdot 6$ \\
\hline Valine & 0.35 & 0.32 & 0.40 & 0.23 & 0.27 \\
\hline
\end{tabular}

Potassium nitrate as repressor. Comparable experiments were performed with $\mathrm{KNO}_{3}$ in

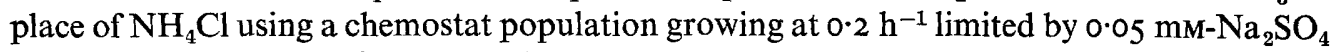
$(0.31$ to $0.32 \mathrm{mg}$ dry $\mathrm{wt} / \mathrm{ml})$. The effect of repressor concentration on degree of repression was similar to that observed with $\mathrm{NH}_{4} \mathrm{Cl}$; free $\mathrm{KNO}_{3}$ was only detected in the culture fluid when the population was fully repressed and the concentrations of $\mathrm{N} / \mathrm{ml}$ required for complete repression were similar: $37 \pm$ I $\mu \mathrm{g} \mathrm{N} / \mathrm{ml}$. The $\mathrm{N}$-content of the completely repressed culture was also $37 \pm \mathrm{I} \mu \mathrm{gN} / \mathrm{ml}$.

Comparable experiments on the effect of population density are included in Fig. 2: as with $\mathrm{NH}_{4} \mathrm{Cl}$, the repressive effect of $\mathrm{KNO}_{3}$ depended on population density. 
Nitrogenase in extracts. The contents of the effluent vessels from several completely repressed, $\mathrm{NH}_{4} \mathrm{Cl}$-grown, $\mathrm{SO}_{4}{ }^{2-}$-limited cultures were harvested, and extracts prepared by sonic disruption. The resulting crude extract was devoid of acetylene-reducing activity. It was chromotographed on DEAE-cellulose 32 and fractions were assayed for acetylenereducing activity alone, in combination and with or without different amounts of substantially purified Azotobacter chroococcum nitrogenase proteins I or 2 (Kelly, 1969). In no case was activity, or enhancement of the low endogenous activity of the protein I or 2 preparations, obtained. Thus completely $\mathrm{NH}_{4}{ }^{+}$-repressed populations were devoid of both nitrogenase proteins.

Amino acid pools. Table 2 shows the free intracellular amino acid and $\mathrm{NH}_{3}$ pool-levels in

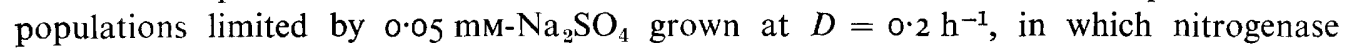
synthesis was unrepressed, half and fully repressed with $\mathrm{NH}_{4} \mathrm{Cl}$ or $\mathrm{KNO}_{3}$. As the degree of repression with either repressor increased the major changes were increases in the levels of $\mathrm{NH}_{3}$, glutamate, aspartate and serine. Glutamine appeared as a small shoulder on the serine peak and could not be measured accurately; however, the shoulder size was small and independent of the degree of repression. Threonine was only detected in fully repressed populations. Casamino acids (Difco), aspartate, glutamate or glutamine at $\mathrm{I} g / \mathrm{l}$ had no effect on nitrogenase synthesis nor on biomass when added to the medium reservoir. Replacement of the $\mathrm{N}_{2}$ in the gas phase by A caused the cultures to wash out, which indicated that none of the compounds tested would serve as a nitrogen source at $D=0.2 \mathrm{~h}^{-1}$. Tests with batch cultures under $\mathrm{A}+0.2$ atm $\mathrm{O}_{2}$ confirmed that they did not serve as nitrogen sources for growth.

Ammonia-assimilating enzymes. GDH and GOGAT were present in almost equal amounts in nitrogen-fixing populations. Growth at the same dilution rate in ammonia- or nitraterepressed conditions made no substantial difference to the ratio or amount of these enzymes (Table 3).

Table 3. Contents of GDH and GOGAT in Azotobacter chroococcum growing at D $=0.2 h^{-1}$ in chemostats limited by $0.05 \mathrm{~mm}-\mathrm{Na}_{2} \mathrm{SO}_{4}$ under $\mathrm{N}_{2}+0.3$ atm $\mathrm{O}_{2}$

Units: nmol NADPH oxidized/mg protein/min.

$\begin{array}{lcc}\begin{array}{c}\text { Added N-source } \\ (\mathrm{mm})\end{array} & \text { GDH } & \text { GOGAT } \\ \mathrm{None} & 40 \cdot 7 & 37 \cdot 6 \\ \mathrm{NH}_{4} \mathrm{Cl}(3 \cdot 7) & 30 \cdot 8 & 28 \cdot 0 \\ \mathrm{KNO}_{3}(2 \cdot 1) & 36 \cdot 4 & 32 \cdot 4\end{array}$

Mono- and trimethylamine and 2-methylalanine as repressors. Sorger (1968) reported that monomethylamine and 2-methylalanine acted as gratuitous co-repressors of nitrogenase synthesis in Azotobacter vinelandii grown with glucose. Either of these compounds, as well as trimethylamine, at I $\mathrm{g} / \mathrm{l}$ increased the lag phase of $\mathrm{N}_{2}$-fixing, sucrose- or mannitol-grown batch cultures of $A$. chroococcum, A. vinelandii (NCIB 8660) and Azomonas macrocytogenes (NCIB 8700 ) in air, compared with $\mathrm{NH}_{4}{ }^{+}$-assimilating cultures. But samples from exponentially growing cultures showed strong acetylene-reducing activity. None of the test compounds, at I $\mathrm{g} / \mathrm{l}$, caused a decrease in population density or acetylene-reducing activity in a continuous culture of $A$. chroococcum $\left(D=0.2 \mathrm{~h}^{-1}\right)$ growing under $\mathrm{N}_{2}+0.3$ atm $\mathrm{O}_{2}$ and limited by $0.05 \mathrm{~mm}-\mathrm{Na}_{2} \mathrm{SO}_{4}$. The populations washed out when A replaced $\mathrm{N}_{2}$ in the gas phase, so these compounds, like the amino acids, were not utilized.

Kinetics of $\mathrm{NH}_{4}{ }^{+}$repression. Diammonium succinate was added to the culture vessel of a 


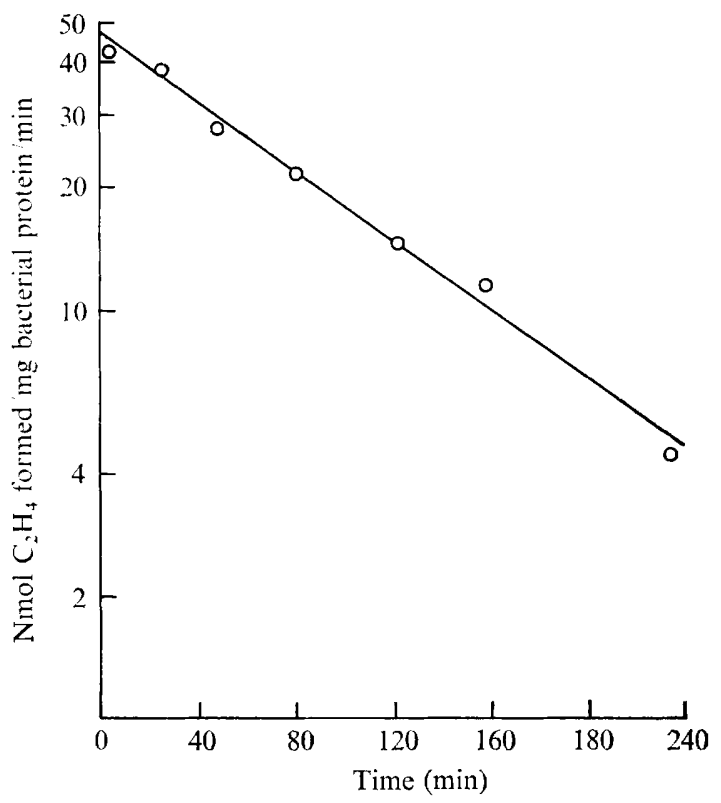

Fig. 3. Kinetics of repression of nitrogenase activity in a chemostat culture of Azotobacter chroococcum. Diammonium succinate $\left(9^{\cdot} 3 \mathrm{mM}-\mathrm{NH}_{4}{ }^{+}\right)$added simultaneously to influent medium and culture vessel of an $\mathrm{SO}_{4}{ }^{2}-$-limited nitrogen-fixing chemostat culture (50 mM- $\left.\mathrm{Na}_{2} \mathrm{SO}_{4}, D=0.25 \mathrm{~h}^{-1}\right)$ growing in air. Free $\mathrm{NH}_{4}$ declined from 9.3 to $5.4 \mathrm{~mm}$ during the experiment; bacterial protein $/ \mathrm{ml}$ culture increased from 0.17 to $0.21 \mathrm{mg} / \mathrm{ml}$.

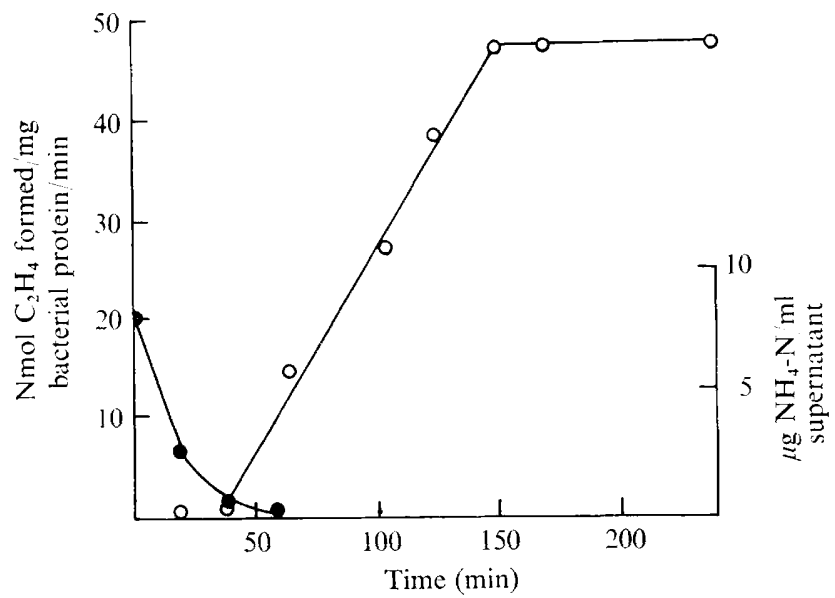

Fig. 4. Kinetics of derepression of nitrogenase activity in a chemostat culture of Azotobacter chroococcum. The medium supply to a $\mathrm{SO}_{4}{ }^{2-}$-limited culture $\left(50 \mathrm{mM}-\mathrm{Na}_{2} \mathrm{SO}_{4}\right)$ growing in air at

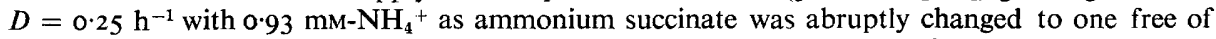
ammonium salts. $O$, Rate of acetylene reduction; $\bullet$, free ammonium ions in culture. 
$\mathrm{N}_{2}$-fixing chemostat culture limited by $\mathrm{Na}_{2} \mathrm{SO}_{4}$, and the medium input at once changed to one introducing a medium containing a similar ammonium concentration. Nitrogenase activity declined logarithmically at a rate faster than predicted if the enzyme simply diluted out (Fig. 3): the half life of the enzyme in Fig. 3 was 72 min compared with a replacement time for the culture of $240 \mathrm{~min}$. Shah et al. (I972) reported logarithmic decline of nitrogenase activity on repression of Azotobacter vinelandii, preceded by a lag. In our chemostat experiments no lag in repression occurred, provided transition to the $\mathrm{NH}_{4}$-containing medium was abrupt (no residual $\mathrm{N}$-free medium in the medium line) and provided the $\mathrm{pH}$ value remained constant. If $\mathrm{NH}_{4} \mathrm{Cl}$ was used and $\mathrm{pH}$ control was omitted, repression appeared to accelerate after a lag as the $\mathrm{pH}$ declined. Ammonium ions also caused an immediate decline of some $30 \%$ in nitrogenase activity as reported by Hardy et al. (I968) even at subrepressive concentrations $\left(0.37\right.$ to $\left.0.55 \mu \mathrm{M}-\mathrm{NH}_{4}{ }^{+}\right) ; \mathrm{KNO}_{3}$ had no such effect. In a single experiment, exogenous $3^{\prime} 5^{\prime}$-cyclic AMP $(5 \mathrm{mM})$ did not prevent ammonia repression; the enzyme activity declined with a half life of 45 min compared with 60 min when tested four generations later without cyclic AMP.

Kinetics of derepression. Fig. 4 shows the rate of resynthesis of nitrogenase following replacement of a medium input containing repressive concentrations of ammonium succinate by one free of available combined nitrogen. Resynthesis started as soon as free ammonium ions could not be detected, proceeded at a linear rate and was complete in $120 \mathrm{~min}$ : about $75 \%$ of the doubling time of the population ( $165 \mathrm{~min}$ ) at the dilution rate used.

\section{DISCUSSION}

The characteristics of Azotobacter chroococcum in sulphate-limited chemostat culture, the relation of biomass to dilution rate and lack of hypersensitivity to oxygen inhibition, were commented on by Hill et al. (1972) and their discussion will not be amplified here.

Regulation of nitrogenase synthesis. In continuous culture the rule seems to be that when sufficient repressor (ammonium or nitrate ions) is added to satisfy the total nitrogen requirements of the population, then nitrogenase synthesis is fully repressed; so the concentration of repressor in the influent medium required for complete repression depends on population density. In $\mathrm{SO}_{4}{ }^{2-}$-limited culture, population density and, therefore, critical repressor concentration is independent of dilution rate. In many natural micro-environments the population densities of azotobacters are low and it may be that the addition of large amounts of $\mathrm{NH}_{4}{ }^{+}$and $\mathrm{NO}_{3}{ }^{-}$fertilizers, by repressing nitrogenase synthesis, will deny azotobacters their principal ecological advantage and their numbers might then decline to a very low level. Macura (1966), in soil perfusion experiments, noted such a decrease in number of azotobacters on adding ammonium salts to a glucose medium otherwise free of fixed nitrogen. The kinetics of synthesis and repression of nitrogenase - its appearance within less than one doubling time and disappearance faster than wash-out - indicates that it is subject to relatively rapid control and turnover in the living organism. We obtained no evidence for an effect of cyclic AMP analogous to its effect on catabolite repression, but it may not have penetrated the organisms. The correlation between content of the internal membrane network described by Oppenheim \& Marcus ( $1970 \mathrm{a}$ ) and nitrogenase content extended to partially repressed populations in steady states, in which all members had a partial complement of membranes; we have drawn attention elsewhere to the fact that this information could only have been obtained by chemostat techniques (Hill et al. 1972). In contrast to the preliminary reports of Oppenheim \& Marcus ( $1970 \mathrm{~b}$ ) and ourselves, we could obtain no consistent reflexion of the membrane contents of organisms in their phospholipid contents, 
when carefully compared at similar population densities and growth rates. We are obliged to attribute our earlier findings to analytical error. The precise function of the membranes remains obscure.

The immediate inhibitory effect of ammonium ions on nitrogenase activity of derepressed populations is unconnected with regulation of enzyme synthesis since it did not occur with nitrate; it was not observed with cell-free nitrogenase preparations from Azotobacter chroococcum (Dr M. Kelly, unpublished) nor from $A$. vinelandii (see Introduction).

Assimilation of fixed $N$. The free amino acid pools are quantitatively typical of those from Gram-negative bacteria (Tempest, Meers \& Brown, 1970) with glutamate and $\mathrm{NH}_{3}$, the predominant constituents, normally present in approximately equimolar concentrations. The free ammonia pool increased only during repression of nitrogenase synthesis. Yet there is likely to be an appreciable concentration of free repressor in $\mathrm{N}_{2}$-fixing organisms because extreme derepression of nitrogenase synthesis can be observed in ammonia-limited populations grown under argon (Dalton \& Postgate, I969b); Gorini \& Maas (I957) associated high levels of production of repressible enzymes with very low intracellular concentrations of repressor. Either aspartate or glutamate could be the true repressor because the pool levels of these increased several-fold (Table 2) respectively. Since they do not enter the organism, they would be ineffective as repressors, or as nitrogen sources, when added to media for growth tests. Parejko \& Wilson (1970) concluded that, of the common organic nitrogen compounds (except urea), only glutamine had any repressive effect on nitrogenase synthesis in Klebsiella pneumoniae. Yoch \& Pengra (1966) measured the free amino acid pools of $K$. pneumoniae in batch cultures (i) when the organisms had just exhausted a limiting $\mathrm{NH}_{4}{ }^{+}$-supply, and (ii) when nitrogenase had just been synthesized. At (i) aspartate, glutamate, and ammonia were in the range 3 to $5 \mathrm{~mm}$; at (ii) the only major difference was that aspartate had dropped to near zero; aspartate, however, had no repressive effect on nitrogenase synthesis even though it was assimilated by the organisms. Like St John \& Brill (1972), we obtained no evidence for repression by Sorger's (I968) ammonia analogues.

Nagatani, Shimazu \& Valentine (1971) suggested that nitrogen fixation and ammonia consumption of Klebsiella pneumoniae followed different assimilatory pathways characterized by the use of GOGAT and GDH respectively. Their experiments, in which pronounced differences in contents of these enzymes were shown, were performed with batch cultures, with which the parameters of growth rate and nutritional status were undoubtedly different. Meers et al. (1970) had earlier shown that the contents of GOGAT and GDH in $K$. aerogenes (syn. Aerobacter aerogenes) were very dependent on growth rate and nutritional status and it is likely that the observations of Valentine and his colleagues were simply a reflexion of this fact. With Azotobacter chroococcum, examined at strictly comparable growth rates $\left(D=0.20 \mathrm{~h}^{-1}\right)$ and nutritional status $\left(\mathrm{SO}_{4}{ }^{2-}\right.$-limitation), we observed no significant difference in assimilating enzymes between nitrogen-fixing organisms and those assimilating ammonia or nitrate.

We are grateful to Dr J. Hall, School of Biological Sciences, University of Sussex, for allowing us to use the electron microscope, and to Miss C. David for helping to operate it and to prepare specimens. We also thank Dr M. Wallis and Mr D. Watson of the above Department for operating the amino acid analyser and Dr M. Kelly, lately of our research Unit, for providing specimens of nitrogenase proteins from Azotobacter chroococcum. 


\section{REFERENCES}

BAKER, K. (1968). Low cost continuous culture apparatus. Laboratory Practice 17, 81 7-824.

Bartlett, G. R. (I959). Phosphorus assay in column chromatography. Journal of Biological Chemistry 234, $466-468$.

Bol TZ, D. F. (1958). Colorimetric Determination of Non-Metals. New York: Interscience Inc.

BoNe, D. H. (1971). Nitrogenase activity and nitrogen assimilation in Anabena flos-aquae growing in continuous culture. Archiv für Mikrobiologie 80, 234-24l.

Daesch, G. \& Mortenson, L. E. ( I968). Sucrose catabolism in Clostridium pasteurianum and its relation to $\mathrm{N}_{2}$ fixation. Journal of Bacteriology 96, 346-351.

Dalton, H. \& Postgate, J. R. (1969a). Effect of oxygen on growth of Azotobacter chroococcum in batch and continuous cultures. Journal of General Microbiology 54, 463-473.

Dal.ton, H. \& Postgate, J. R. (I969b). Growth and physiology of Azotobacter chroococcum in continuous culture. Journal of General Microbiology 56, 307-319.

Davis, L. C., Shah, V. K., Brill, W. J. \& Orme-Johnson, W. H. (1972). Nitrogenase. II. Changes in the EPR signal of component I (iron-molybdenum protein) of Azotobacter vinelandii during repression and derepression. Biochimica et biophysica acta 256, 512-523.

Drozd, J. W. \& Postgate, J. R. (1970). Effects of oxygen on acetylene reduction, cytochrome content and respiratory activity of Azotobacter chroococcum. Journal of General Microbiology 63, 63-73.

Folch, J., Lees, M. \& Sloane-Stanley, G. H. (1957). A simple method for the isolation and purification of total lipids from animal tissues. Journal of Biological Chemistry 226, 497-506.

Goerz, R. D. \& Pengra, R. M. (196I). Physiology of nitrogen function by a species of Achromobacter. Journal of Bacteriology 81, 568-572.

Gorini, L. \& MAAs, W. K. (I957). The potential for the formation of a biosynthetic enzyme in Escherichia coli. Biochimica et biophysica acta 25, 208-209.

Hardy, R. W. F., Holsten, R. D., JaCKson, E. K. \& Burns, R. C. (I968). The acetylene-ethylene assay for $\mathrm{N}_{2}$ fixation - laboratory and field evaluation. Plant Physiology 43, 11 85-1 207.

Hill, S., Drozd, J. W. \& Postgate, J. R. (1972). Environmental effects on the growth of nitrogen-fixing bacteria. Journal of Applied Chemistry and Biotechnology 22, 54I-558.

Kellenberger, E., Ryter, A. \& Sechaud, J. (1958). Electron microscope study of DNA-containing plasms. II. Vegetative and mature phase DNA as compared with normal bacterial nucleoids in different physiological states. Journal of Biophysical and Biochemical Cytology 4, 671-676.

Kelly, M. (1969). The properties of purified nitrogenase of Azotobacter chroococcum. Biochimica et biophysica acta $\mathbf{1 7}$, 9-22.

Kelly, M., Klucas, R. V. \& Burris, R. H. (1967). Fractionation and storage of nitrogenase from Azotobacter vinelandii. Biochemical Journal ro5, 3c-5c.

LASCEll.es, J. \& SzILAGYI, J. R. (1965). Phospholipid synthesis by Rhodopseudomonas spheriodes in relation to the formation of photosynthetic pigments. Journal of General Microbiology 38, 55-64.

LUFT, J. M. (1961). Improvements in epoxy resin embedding methods. Journal of Biophysical and Biochemical Cytology 9, 409-4I4.

Macura, J. (1966). Continuous flow methods in soil microbiology. In Theoretical and Methodological Basis of Continuous Culture of Microorganisms, pp. 470-472. Edited by I. Malek and Z. Feud. Prague: Czechoslovak Academy of Sciences.

MAHL, M. C. \& WILSON, P. W. (1967). Nitrogen fixation by cell-free extracts of Klebsiella pneumoniae. Canadian Journal of Microbiology 14, 33-38.

Mrers, J. L., Tempest, D. W. \& Brown, C. M. (1970). 'Glutamine (amide): 2-oxoglutarate amino transferase oxido-reductase (NADP)', an enzyme involved in the synthesis of glutamate by some bacteria. Journal of General Microbiology 64, 187-194.

Munson, T. O. \& Burris, R. H. (1969). Nitrogen fixation by Rhodospirillum rubrum grown in nitrogenlimited continuous culture. Journal of Bacteriology 97, 1093-I098.

Nagatani, H., Shimazu, M. \& Valentine, R. C. (1971). The mechanism of ammonia assimilation in nitrogen-fixing bacteria. Archiv für Mikrobiologie 79, I64-175.

Nellson, A., RipPKA, R. \& Kunisawa, R. (1971). Heterocyst formation and nitrogenase synthesis in Anabena sp. - a kinetic study. Archiv für Mikrobiologie 76, I 39-1 50.

OpPenheim, J. \& MARCus, L. (1970a). Correlation of ultra-structure in Azotobacter vinelandii with nitrogen source for growth. Journal of Bacteriology Ior, 286-291. 
OpPenheim, J. \& MARCus, L. (1970 $b$ ). Induction and repression of nitrogenase and internal membranes in Azotobacter vinelandii. Bacteriological Proceedings, 148.

PANGBorn, J., MARR, A. G. \& RoBrish, S. A. (I962). Localisation of respiratory enzymes in intracytoplasmic membranes of Azotobacter agilis. Journal of Bacteriology 84, 669-678.

Parejko, R. A. \& Wilson, P. W. (I970). Regulation of nitrogenase synthesis by Klebsiella pneumoniae. Canadian Journal of Microbiology I6, 68I-685.

Postgate, J. R. \& Hunter, J. R. (1962). The survival of starved bacteria. Journal of General Microbiology zy, 233-263. Addendum, (1963), Journal of General Microbiology 34, 473.

REYNOLDS, E.S. (1963). The use of lead citrate at high $\mathrm{pH}$ as an electron-opaque stain in electron microscopy. Journal of Cell Biology 17, 208-2 I 2.

Roberts, R. B., Abelson, P. H., Cowrie, D. B., Bolton, E. T. \& Britten, R. J. (1955). Studies on Biosynthesis in Escherichia coli. Publication 607. Washington D.C.: Carnegie Institution.

St JohN, R. T. \& BRILL, W. S. (1972). Inhibitory effect of methylalanine on glucose-grown Azotobacter vinelandii. Biochimica et biophysica acta 26r, 63-69.

ShaH, V. K., Davis, L. C. \& BRILL, W. J. (I972). Nitrogenase. I. Repression and derepression of the ironmolybdenum and iron proteins in Azotobacter vinelandii. Biochimica et biophysica acta 256, 498-5I I.

Sмith, R. V. \& Evans, M. C. W. (1970). Soluble nitrogenase from vegetative cells of the blue-green alga Anabaena cylindrica. Nature, London 225, I 253-I 254.

SORGer, G. J. (1968). Regulation of nitrogen fixation in Azotobacter vinelandii OP and in an apparently partially constitutive mutant. Journal of Bacteriology 95, 1721-1726.

StrandBerg, G. W. \& WiLson, P. W. (1968). Formation of the nitrogen-fixing enzyme system in Azotobacter vinelandii. Canadian Journal of Microbiology 14, 25-3I.

Tempest, D. W., Meers, J. L. \& Brown, C. M. (I970). Influence of environment on the content and composition of microbial-free amino acid pools. Journal of General Microbiology 64, 17I-I 85 .

Wilson, P. W. (1958). Asymbiotic nitrogen fixation. In Encyclopedia of Plant Physiology, 8, pp. 9-47. Edited by W. Ruhland. Berlin: Springer.

Yoch, D. C. \& Pengra, R. M. (I966). Effect of amino acids on the nitrogenase system of Klebsiella pneumoniae. Journal of Bacteriology 92, 618-622. 